\title{
EGZEGEZA IV EWANGELII W PISMACH OJCOW APOSTOLSKICH
}

Wybitny znawca dziejów starożytnego Kościoła, L. Duchesne, wygłosil niegdyś opinię, którą warto przypomnieć: "Dla chrześcijaństwa wazne jest nie tyle to, co zwykliśmy nazywać prehistorią ewange111, 1le raczej jej oddziaływanie na zycie religijne Kościoła" 1 . Współczesna egzegeza zanotowała bez wątpienia wiele osiągnięć w badaniach nad prehistoria ewangelii. Istnieja jednak nadal uzasadnione mątpliwośc1, czy doniosłe - zdaniem L. Duchesne - zagadnienie recepcji ewangel11 wierwszych wspólnotach chrześcijańskich cieszy się przynajmniej równym zainteresowaniem uczonych.

Starozytność chrześcijańska moze poszczycić się monumentalnymi komentarzami do ewangeli1 św. Jana. Serie ich otwiera Orygenes ${ }^{2}$, którego dzieło, jakkolwiek po części tylko zachowane, daje wyobrazenie o rozległośc1 problematyki egzegetycznej zasygnalizowanej woczatkach III wieku. Totez z tym większą natarczywościa nasuwa sle pytanie co do stanu egzegezy ewangeli1 Jana przed Orygeriesem, która wziele wielkiego Aleksandryjczyka otrzymała tak wspaniałe zwieńczenie.

Artykuz niniejszy ma na celu ukazanie wycinka dziejów egzegezy IV ewangelil przed pojawieniem się wielkich komentarzy. Poniewaz świadectw chrześcijańskich z II w. jest wiele, tutaj ograniczymy się jedynie do pism Ojców Apostolskich, a w szczególności do Listu

1 L. Ducheșne, Histoire ancienne de l'Eglise, Paris 1907/10, 148.

2 Origenes, Commentarius in Evangelium secundum Joannem, libri XXII, SCh 120, 157, 222, 290, przekład S. Kalinkowsk1, PSP 28. Inne komentarze starozytne: S. Augustinus, In Joannis Evangelium tractatus 124, CCL 36, tłum. W. Szołdrski, PSP 15; Joannes Chryzostomus, In Joannis bvangelium homfliae LXXXVIII, PG 59, 23-482; Theodorus Mopsuestenus, Commentari1 in Joannem/syriace/, CSCo $115 /$ textus/, csco $116 /$ translatio/; Cyrillus Alexandrinus, Commentariorum in Joannis Evangelium 11 bri XII, PG 73 i $74,9-756$. 
św. Klemensa Rzymskiego do Koryntian, listów św. Ignacego Antiocheńskiego i Listu Barnaby.

\section{LIST SW. KLEMENSA DO KORYNTIAN}

Jednym $z$ najwcześniejszych pozakanonicznych świadectw chrześcijańskich, jest napisany ok. 96 r., po zakończeniu prześladowań za Domicjana, list św. Klemensa Rzymskiego do Koryntian ${ }^{3}$. Trudno dokładnie określić, na ile był on inspirowany ewangelią św. Jana. W tej kwestil bowiem istnieje znaczna różnica poglądów. Wlększość egzegetów, zwłaszcza dawniejszych, nie znajduje w nim niczego, co byłoby typowo Janowe ${ }^{4}$, inni natomiast Pormułuja sąd przeciwny ${ }^{5}$. Ostatnio coraz więcej zwolenników zyskuje opinia o wpływie środowiska Janowego, nie zaś Ewangelii juz napisanej ${ }^{6}$. Zechciejmy zatem przyjrzeć się tym miejscom z Listu do Koryntian, które zazwyczaj przyciągają uwagę egzegetów.

\footnotetext{
"Apostołowie zostali do nas posłani z Dobra Nowiną przez Jezusa Chrystusa. Jezus Chrystus zaś wysłany został przez Boga. Tak więc Chrystus od Boga, apostołowie od Chrystusa. Jedno 1 drugie dokonalo się zgodnie z Wolą Bożą"7.
}

3 Epistola ad Corinthios, SCh 167, tłum. A. Lisiecki POK 1, 106-167. Odpowiednie cytaty podaję jednak w tłumaczeniu własnym.

4 "Auf Aussagen uber ein Joh - Verständnis im I Clem. muss nach alledem verzichtet werden". W. v. Loewenich, Das Johannes - Verstandnis im zweiten Jahrhundert, Giessen 1932, 6; podobnie M. Goguel, Introduction au Nouveau Testament, II. Ie quatrième Evangile, Paris 1924, 112: "La premiére ép̂ttre de Clement Romain /environ 95/ ne connaît que la tradition sinoptique".

5 Z wcześniejszych autorów por. T. Zahn, Geschichte des Neutestamentliche Kanons, Erlangen - Lipzig 1892, 908: "Sehr wahrscheinlich, dass damals in Rom das 4 Ev. gelesen wurde". Podobnie: C. Tarelli, Clement of Home and the fourth Gospel, JTS 48/1947/208 n.; P. Boisuard, Clement de Rome et l'Evangile de Jean, RB 55/1948/376-387.

6 Por. As Jaubert, Introduction, $\mathrm{SCh}$ 167, 56: "Nous supposerions, quant a nous, qu'un vaste coúrant judéo - chrétien, où s'alimentait le milieu johannique, véhiculait Jusqu'à Rome, deputs la Palestine, la Syrie, I'Asie Mineure, un certain nombre de thèmes et de priéres liturgiques dont on ne peut plus s'étonner qu'ils soient communs à 1 "évangile de Jean".

Epistola ad Corinthios 42, 1-2, SCh 167, 168. 
Juz na pierwszy rzut oka zauważyć mozna nawiązanie do Janowej Idei posłannictwa. Klemens podkreśla wspólne źródło posłannictwa

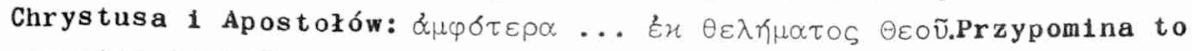
mersety: "Jak Ty Mnie posłałés na świat, tak 1 Ja ich na świat posłałem" /J 17, 18/ oraz "Jak Mnie posłał ojciec, tak 1 Ja was posyłam" $/ \mathrm{J} 20,21 /$.

W obydwu tekstach Janowych fakt przedłużenia misji Chrystusa

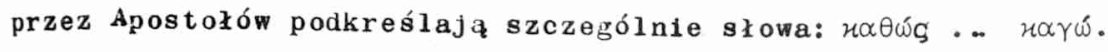
W J 20, 21 występuje ponadto czasownik $\pi \varepsilon \mu \pi \omega / K 1$ em.: $\varepsilon \xi \varepsilon \pi \varepsilon \mu \varphi \theta \eta /$. Jan używa go zazwyczaj na określenie posłannictwa Jezusa /4, 34; 5 , 23 nn.; 6, 38 n. 1 in./ oraz Dwunastu /13, 16.20/. Powyższy tekst Klemensa, jak widać, nie jest wprawdzie cytatem ewangelicznym, jednakze myrażona wim idea jest tak dalece Janowa, iz jej pojawienie się niezależnie u obu autorów wydaje się mało prawdopodobne ${ }^{8}$.

W 43 rozdziale listu jest mowa o wydarzeniu, przez które Bóg wyznaczył Aarona na arcykapłana /Lb 17, $16 \mathrm{nn}$ /. Na zakończenie autor stwierdza:

"Stało sie to, aby uwielbione było Imię Prawdziwego Jedynego . Jemu chwała na wieki wieków. Amen"10.

Powyższa wypowiedź wskazuje na liczne powiazania z Ewangelią Janową. Przypomina nade wszystko początek modlitwy arcykapłańskiej: "/.../ aby poznali Ciebie, jedynego prawdziwego Boga" /J 17,3/. W obrębie Nowego Testamentu przymiotnik $\alpha \lambda \eta \theta \iota \nu \sigma ́ s$ jest typowy dia słownictwa Janowego. Wyjąwszy 1 Tes 1, 9 tylko Jan stosuje go do Boga. Oprócz

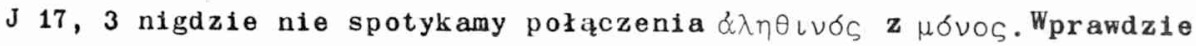

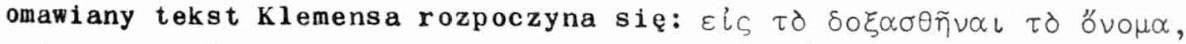

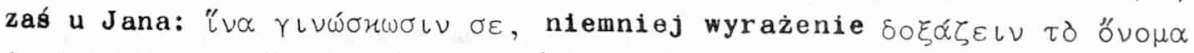
jest także wyrażeniem Janowym $/ 12,28 /$, a cały kontekst J 17,3 dowodzi, iż idzie tu o uwielbienie Imienia Boga ${ }^{11}$.

8 F. M. Braun, Jean le Théologien, Paris 1959, 174.

9 Niektóre kodeksy dodają tym miejscu $\theta \varepsilon O \tilde{u} / \mathrm{S}, \mathrm{C} 1 /$, co w szczególny sposób nawiazuje do J 17, 3. Inne pozostawiaja tutaj miejsce puste /A/.

10 Epistola ad Corinthios $43,6, \operatorname{SCh} 167,172$.

11 Por. F. M. Braun, Jean le Théologien, dz.cyt., 175. 
W Iiście Klemensa Kościół nazwany jest wielokrotnie owczarnią Chrystusa:
"/.../ niech tylko owczarnia Chrystusa żyje w pokoju z ustanowionymi prezbiterami"12; "Lepiej dla was być małymi 1 nie znaczącymi wóród wybranych $z$ owczarni Chrystusa, niź odbierać wielkie zaszczyty i być od- rzuconym od Jego nadziei"13; "Uważamy, iż ci, którzy wypełnili swój obowiazzek względem owczarni Chrystusa nienagannie, z pokora/.../, nie powinni być złozehi z urzędu"14.

Idea owczarn1 jest bardzo charakterystyczna dla ewangelii Jana/10, 2-6. 26-28/15. Poza nią oraz $1 \mathrm{Pt} 5,2 /$ "paście trzodę Bozą"/ nie znajdziemy nigdzie Kościoła przedstawianego w obrazie owczarni Chrystusa. Zależność Klemensa od któregoś spośród tych autoróm jest więc wysoce prawdopodobna.

Przedłożone powyżej teksty z listu Klemensa wskazują na pewien związek $z$ odpowiednimi fragmentami ewangelii Janowej. Mozna byłoby podać ich więcej ${ }^{16}$. Nie są to wszakże jedyne znaki łączności obydwu pism. Oprócz podobnych sformułowań nierzadko łączą oba pisma wspólne tematy teologiczne. Przykładem jest temat Imienia. Wiadomo, $1 \dot{z}$ w ewangelii Jana naleźy on do głównych, zwłaszcza w rozdz. 17 i łączy się z tenatem chwały ${ }^{17}$. Obydwa pojawiaja się często u Klemensa. Przez Chrystusa Bóg ma być uwielbiony na wieki wieków ${ }^{18}$, przezeń powołał nas Bóg nie tylko do poznania chwały Jego Imienia ${ }^{19}$, lecz

12 Epistola ad Corinthios 54, 2, SCh 167, 186.

13 Tamże, 57, 2, SCh $167,190$.

14 Tanże, 44, 3, SCh 167,172 .

15 Biblijny obraz Pasterza pojawia się także w innych pismach N.T. /Mk 14, 27; Mt 26, 31; Łk 12, 32; Dz 20, 28-29; I Pt 2, 25; 5, 2. 4; Hbr 13, 20/ nie ulega jednak wątpliwości, iż obraz ten otrzymał szczegóine miejsce w teologicznej koncepcji Jana Ewangelisty.

16 Por. Jeszcze: Klem 60, 2 - J 17, 17; 15, 3; Klem 59, 3 - J 12, 26; Klem 43, $6-\mathrm{J} 17,1,6$; Klem 58, 1 - J 17, 11 itp.

17 Por. W. Grossouw, La glorification de Christ dans le quatrième Evangile, Evangile de Jean, Louvain 1957, 130-145; 0. Merlier,

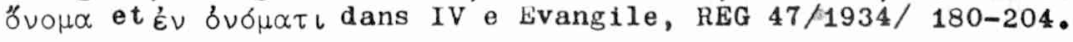

18 Epistola ad Corinthios 48, 2, SCh 167, 178; por. 20, 11; 38, 4.

19 Tamże, 59, 2, SCh 167, 194 . 
także udzielenia jej tym, którzy w Nim pokładają swą ufnośćc 20. Stąd chrześcijanie moga i powinni zwracać się ku świętemu 1 chwalebnemu Imieniu 1 wim upatrywać swe bezpieczeństwo ${ }^{21}$. Temat skutecznośc1 modlitwy w Imię Jezusa, znany w IV ewangelii /14, 13; 16 , 24. 26/ pojawia sie także bardzo wyraźnie u Klemensa, zwaszcza w wystepujacych tam formukach liturgicznych ${ }^{22}$.

Podsumujmy dotychczasowe spostrzeżenia. Pomiędzy. ewangelia Jana a listem Klemensa istnieje bez wątpienia jakis zwiazek. Jest prawdopodobne, iz Klemens znał IV ewangelie. W takim wypadku jego list byłby świadectwem najstarszego rozumienia 1 wyjaśniania ewangelii św. Jana. Ową znajomość trudno jednak udowodnić, bowiem w piśmie Klemensa nie znajdziemy ani jednego wyraźnego cytatu ewangel11. Z tego właśnie powodu uczeni skłonni sa mówić o wspólnym jakoby klimacie, z którego wyrosia IV ewangelia, towarzyszącym Kościołowi Rzymskiemu, a zatem 1 Klemensow ${ }^{23}$. Wydaje sie, iz zajecie odpowiedniego stanowiska w tej kwestii będzie możliwe dopiero po zbadaniu innych świadectw pochodzących z tego okresu.

\section{LISTY SW. IGNACEGO}

0 związkach listów św. Ignacego 24 z IV ewangelia egzegeci wypowiadaja się na ogół bardziej przychylnie, niż miało to miejsce w wypadku Klemensa ${ }^{25}$. Zapewne odgrywa tutaj jakáś role bogatszy

20 Tamże, 45,8, SCh $167,174$.

21 Tamże, 58, $1, \operatorname{SCh} 167,192$.

22 Por. tamże, 20, 11; 38,$4 ; 43,6 ; 45,8 ; 58,2, \operatorname{SCh} 167,136$, $162,170,174,192$.

23 Por. A. Jaubert, Introduction, SCh 167, 53: "Ẹtre l'évangile de Jean et la premiére épître de clément li nexiste, de l aveau de tous, aucun rapprochement littéraire direct. Il y a pourtant un probième des contactsentre epitre de clément et ce qu on pourrait appeler le milieu johannique". Por. F. M. Braun, dz॰cyt.,
180.

24 Ep1stolae Ignati1 Ant1ochen1, SCh 10, tłum. A. Lisieck1, POK 1, 206-247. Cytowane fragmenty podajemy jednak we własnym przekładzie.

25 Por. W. Loewentch, Das Johannes, dz.cyt., 25-26: "Auch die Gegner elner litefarischen Bekanntschaft mtssen hier von einer tberraschenden tbereinstimmung /.../ sprechen, die nicht zufallig sein
kann". 
materiał porównawczy. Przede wszystkim także 1 tutaj zauwazamy szereg wyrażeń, których przynaleźność do słownictwa Janowego wydaje się uderzaj६̨ca. Tak więc na przykıad Ignacy pisał o winnicy Pańskiej ${ }^{26}$, Księc1u tego świata ${ }^{27}$, chlebie $\mathrm{Boga}^{28}$, bramie ojca ${ }^{29}$, Pasterzu owiec ${ }^{30}$, Jedynym Nauczycielu ${ }^{31}$. w jego listach pojawiają się takze dłuzsze zwroty charakterystyczne dla ewangelisty: "Pan niczego nie czyni bez ojca"32, "abyścle uświęceni byl1 we wszystkim"33, "Chrystus nasze życien 1 inne.

Na szczególną uwage zasługują jednak wypowiedzi, które bardzo wyraźnie przywołuja na pamięć podobne z ewangelil Janowej. Wymieńmy te najbardziej typowe.

"Jeden jest tylko Bóg, objawiony przez Jezusa Chrystusa, Syna Jegro, który jest Słowem wyłonionym z milczenia, który we wszystkim spodobał się Temu, który Go posłał" ${ }^{35}$.

Trzy racje przemawiają za tym, iz Ignacy pisał te słowa pod wpływem J 8, 29: "A ten, który Mnie posłał, jest ze Mnz: nie pozostawił Mnie samego, bo Ja zawsze czynię to, co się Jemu podoba". Czasownik Eú-

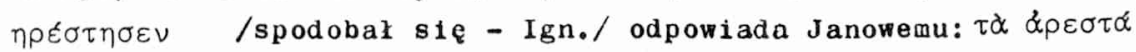
/to, co się podoba/. Myśl, 1ż Chrystus czyni zawsze to, co się Ojcu podoba, jest typowo Janowa/por. J 4, 34; 5,$30 ; 6,38-40 ; 7$, 18; 14, 21/, a zwiazek pomiędzy obydwoma terminami jest tym bardziej prawdopodobny, iz w słonnictwie listów rzadko spotykamy pokrewne cza-

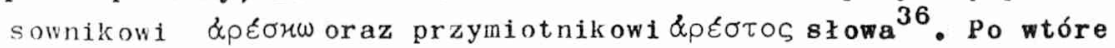
konstrukcja przyimkowa: $\varkappa \alpha \tau \downarrow$ - $\tau \alpha \nu \tau \alpha$ /we wszystkim - Ign./ odpowiada

26 Epistola ad Trallianos 11, 1, SCh 10, 102.

27 Epistola ad Ephesios 17, 1; Epistola ad Magnesios 1,2; Epistola ad Romanos $7,1, \operatorname{SCh} 10,72,80,114$.

28 Epistola ad Ephesios 5, 2, SCh 10, 62.

29 Epistola ad Philadelphienses 9, 1, SCh 10, 128.

30 Tamze, 2, 1, SCh 10, 120.

31 Epistola ad Magnesios 9, 1, SCh 10, 88; por. J 13, 13.

32 Epistola ad Magnesios 7, 1, SCh 10,84; por. J 5, 19. 30; 8, 28.

33 Epistola ad Ephesios 2, 2, $\operatorname{SCh} 10,58$; por. J 17, 19.

34 Tauże, 3, 2; Epistola ad Magnesios 1, 2, $\mathrm{SCh} 10,60,80$; por. J 11, $25 ; 14,6$.

35 Epistola ad Magnesios 8, 2, $\operatorname{SCh} 10,86$.

36 C. Maurer, Ignatius von Antiochien und das Johannesevangelium, Zur1ch 1949. 
$\pi \alpha \nu \tau \circ \tau \varepsilon$ u Jana. Wreszcie imiesłów: $\pi \varepsilon \mu \psi \alpha \nu \tau \iota / T e m u$, który posłał Ign./ posiada kilkadzlesiąt paralelnych wyraźeń w IV ewangelii 1 wskazuje zazwyczaj na posłannictwo Syna. W tym samym liście do Magnezjan, nieco wcześniej czytamy: "Pan niczego nie dokonał bez ojca"37. Wypowiedz ta wyraźnie przypomina $J$ 8, 28: "Ja nic od siebie nie czynie, ale to mówię, czego Mnie ojciec nauczył".

\footnotetext{
"Niektórzy pragną wprowadzać mnie w błąd według ciała, ale nie można zmylić Ducha, który od Boga pochodzi. Wie on bowiem, skad idzie i dokad przychodzi 1 on objawia tajemnice. Wołałem, gdy byłem wóród was, wołałem głośno głosem Boya: Trwajcie w łączności z biskupami"38.
}

Az trzy teksty Janowe przychodzą tu na pamięć: J 3, 8: "Wiatr wieje tam, gdzie chce, 1 szum jego słyszysz, lecz nie wiesz, skąd przycho-

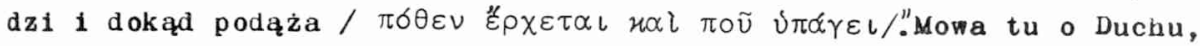
którego symbolem jest wiatr. Jan nie mówi wprost, iz Duch wie, skąd przychodzi 1 dokąd podazza/Ign./, ale wynika to z kontekstu, w którym upidoczniona została niewiedza ludzi w tej materi1. Drug1 tekst pochodzi z zanotowanej przez Jana dyskusji Jezusa z żyami: "wiem, skąd przyszedłem 1 dokąd idę. Wy zaś nie wiecie, ani skąd przychodzę, an1 dokąd idę. Wy wydajecie sąd wedlug zasad tylko ludzkich" /J 8 ,

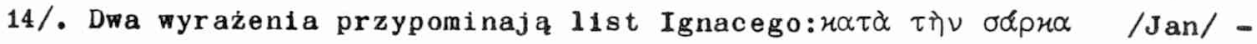

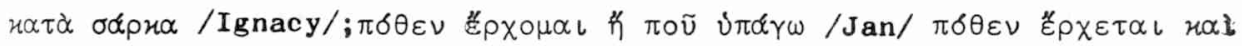

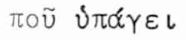
/Ignacy/. W drugim wypadku róznica płynie stad, iż w ewangelii Jezus mówi o sobie/stąd 1 osoba liczby pojedynczej/, zaś Ignacy mówi o Duchu. W obydwóch wypowiedziach pojawia się to samo przeciwstawienie wiedzy jednego, ignorancji drugiego. Wreszcie J 7,28-29;"A Jezus (...) zawołał tymi słowami: I Mnie znacie, 1 wiecie, skąd jestem. Ja jednak nie przyszedłem sam od siebie; lecz prawdziwy jest tylko Ten,który Mnie posłał,którego wy nie znacie".Powyższa wypo. wied́ zawiera prawie tą samá ný́l co J 8, 14. Różnica polega na pod-

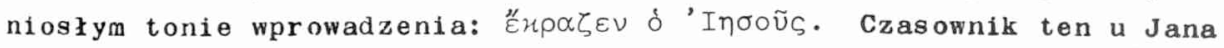

37 Epistola ad Magnesios $7,1, \operatorname{SCh} 10,84$.

38 Epistola ad Philadelphienses 7, 1, SCh 10, 126. 
oznacza: ogłaszać na sposób proroków. Ignacy miał prawdopodobnie w pamieci owe uroczyste znaczenie, kiedy używał podobnie brzmiacego

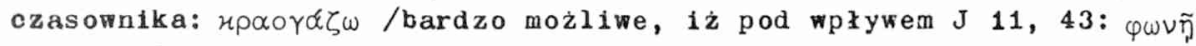

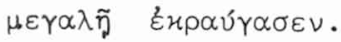

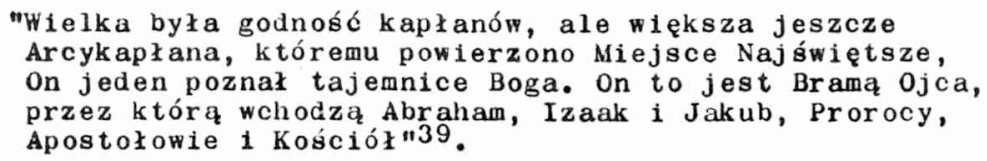

Pomijając początek, wywodzący się prawdopodobnie z listu do Hebrajczyków $/ 7,11.25 /$, podany tekst przypomina dwie wypowiedzi Jezusa z ewangel1i Jana: "Zaprawdę, zaprawdę, powiadam wam: Ja jestem bramą owlec" / 10, 7/ oraz: "Ja jestem brama. Jeżeliktoś wejdzie przeze Mnie, będzie zbawiony - wejdzie 1 wyjdzie, 1 znajdzie paszę" /10, $9 /$. Pomiędzy powyzszym Pragmentem listu do Filadelfian a J 10, 9 istnieJe wielorakie podobieństwo: wednym 1 drugim tekście obraz bramy zastosowany jest do osoby Jezusa, w jednym 1 drugim jest mowa

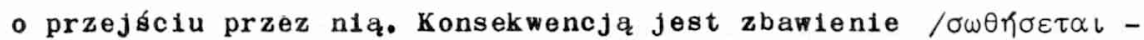

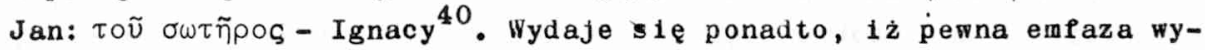
powiedzi Janowej: દ̌ץẃ $\varepsilon i \mu \iota$, zachowana została w sformułowaniu Igna-

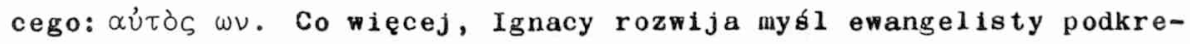
ślając, iź Jezus jest bramą wlodącą do ojca: "On jest bramą 0jca". Ta ostatnia myśl odpowiada doskonale słowom Jezusa J 14, 6: "Ja jestem drogái prawdą $i$ życiem. Nikt nie przychodzi do ojca inaczej, jak tylko przeze Mnie".

Latwo zauwaźyć, że przytoczony wyżej fragment listu do Filadelfian $/ 9,1 /$ jest zbiorem reminiscencji IV ewangel11. Podobieństwa wydaja sie jeszcze bardziej uderzajace, niz miało to miejsce w wyadku listu Klemensa ${ }^{41}$. Nadal jednak brak pełnego cytatu z ewangelii Janowej, który definitywnie przesądziłby sprawę związku Ignacego z IV

39 Epistola ad Philadelphienses 9, 1, SCh 10, 128.

40 Tamze, 9, 2, SCh 10, 128.

41 W. v. Loewenich, dz.cyt., $26 \mathrm{nn}$. 
ewangelią42. Zbadajmy więc jeszcze jedno świadectwo tego okresu, pochodzące z Kościoła w Egipcie, tzw. list Barnaby ${ }^{43}$.

\section{LIST BARNABY}

W starożytności list ten uchodził za dzieło apostoła Barnaby ${ }^{4}$. W rzeczywistoścl o jego autorze mozemy powiedzié tylko tyle, 1z by chrześcijaninem nawróconym z żydostwa 1 dzieło swe napisał prawdopodobnie w Aleksandri1, nie później niź w 130 roku.

Winteresującej kwestii wypadnie nam potwierdzić dotychczasowe spostrzeżenia. I $\mathbf{w}$ tym liście na próżno szukalibyśmy cytatu z IV ewangelii. Istnieją jednak duże podobieństwa zarómno w aspekcie doktrynalnym, jak 1 literackim. Szczególnie chrystologia listu posiada sporo elementów wspólnych z Janową: Jezus jest objawionym w ciele Synem Bożym ${ }^{45}$, który przyszedł, aby zniszczyé śmieró 1 przynieść zmartwychwstanie 1 w ten sposób dokonać sądu ${ }^{46}$. Objawil siebie przez znaki $i$ cuda. Żydzi jednak nie uwierzyli 47 , ufając swej wiasnej sprawiedliwości 48 . Mimo to pozostał w ciele 49 , aby za nasze grzechy przyjąć cierpienie Krzyża zapowiedziane ofiarą Izaaka ${ }^{50}$. W ten sposób stał sie naczyniem Ducha ${ }^{51} 1$ źródłem wody żywej, która

42 Stąd tez w swoim czasie hipoteza o istnieniu szkoły teologicznej w Azj1, z której zarówno Jan, jak 1 Ignacy mieliby czerpać w podobny sposób. Por. E. v. Goltz, Ignatius von Antiochien als Christ und Theologe. E1 ne dogmengeschichtliche Untersuchung/TU $12,3 /$, Leipzig 1894 .

43 Epistola Barnabae, SCh 172, tłum. A. Lisieck1 POK 1, 53-93. Przy cytowaniu posługujemy się jednak wasnym przekładem.

44 Por. Clemens Alexandrinus, Stromateis II 8, 5; Origenes, Contra Celsum I 64; Eusebius, Historia ecclesiastica III 25, 4; VI 13, 6; Hieronymus, De viris illustribus 111, 6 .

45 Ep1stola Barnabae 5, 6; 7, 14; 12, 10, $\operatorname{sch} 172,108,136,172$; por. $1 \mathrm{~J} 3,8$.

46 Tamze, 5, 6-7, SCh 172, 108; por. J 5, 24-28; 8, 51; 11, 25 n.; 12,47 .

47 Tamże, 4, 7, SCh 172, 96-98.

48 Tamże, 4, 10, SCh 172, 100; por. 4, 48.

49 Tamże, 5, 6, SCh $172,108$.

50 Tanże, 7, 3, SCh 172, 128-130; por. J 3, 16 .

51 Tamże, 7,3 i 11, 9 , SCh $172,128-130$ i 164 . 
łączy się ściśle z ofiarą Krzyża ${ }^{52}$, wodą żywą zapowiedzianą przez proroków jest woda chrztu. Przynosi błogosławieństwo tym, którzy swą ueność pokładają $\mathrm{Krzy}^{53}$.

\begin{abstract}
"Wstępujemy do wody obciążeni grzechami i nieprawościami, wychodzimy zaś ubogaceni na sercu, majac przez Ducha bojaźń i nadzieję W Jezusie. Ktokolwiek pożywać będzie z tych owoców, żyć będzie na wieki; zaprawdę, ktokolwiek usłyszy i uwierzy w to, co mówią prorocy, będzie żyé na wieki" 54 .
\end{abstract}

Dlatego odtąd chrześcijanin powołany jest 1 zobowiązany do postępowania w światłości ${ }^{55}$.

Powyższe podobieństwa doktrynalne /objawiente Jezusa w ciele,

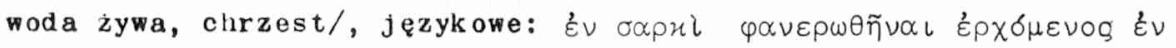

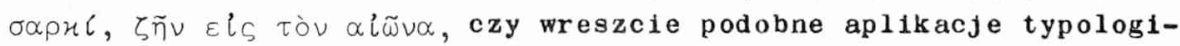
czne /zarómno Barn 12, 5-7, jak $1 \mathrm{~J} 3,14$ dopatrują się w miedzianym wężu z Lb 21 typu Krzyża Chrystusa/ nie wskazują na konieczność przyjęcia bezpośredniego korzystania z IV ewangelii przez autora Listu ${ }^{56}$. Omów1ente, w miarę dokładne, powyżsych trzech starożytnych dokumentów pozwala na sformułowanie kilku wniosków:

$1^{0}$ omawiane świadectwa /Klem, Ign, Barn/ pochodzaz z tego samego okresu, tj. przełomu I 1 II wieku. Pod względem geograricznyı reprezentują Kościół fizymski /Klem/, Kościoły Azji/Ign/ oraz Kościół Egiptu/Barn/;

$2^{\circ}$ wszystkie zdradzajaz pewne podobieństwa 1 zwiazzek $z$ ewangelią Jana, ale zaden nie dostarcza przekonywającego dowodu, ż ich autor posłuyiwał się ewangelia Jana w jej ostatecznym kształcie. Stąd podawane najczęściej rozwizzanie: autorzy pozostawali pod

52 Epistola Barnabae, 11, 1, 8, SCh 172, 158-160; por. J 7, 37-39.

53 Tamze, $11,8, \mathrm{SCh} 172,164 ;$ por. J $3,5-51$.

54 Tamze, 11, 11, SCh 172,$166 ;$ por. J 3, 15. 16. 55 Tamze, 18-19, SCh 172, 194-210; por.J 1, 7 .

56 Por. W. Loewenich, Das Johannes, dz.cyt., 18: "Hat er auch Joh. gekannt? Wir konnen es nicht boweisen, freilich ebensowenig das Gegenteil. Wir werden uns mit elnen non liquet bescheiden melssen". F. M. Briaun, Jean le Théologien, dz.cyt., 85: "On serait ainsi enclin a supposer que le Pseudobarnabé connaissait un Evangile de Jean d'avant la lettre". 
mpływem środowiska Janowego, nie zaś ewangelii Jana, której najwidoczniej nie znali;

$3^{0}$ przyjęciu hipotezy środowiska Janowego stoi na przeszkodzie wątpliwość czy istotnie mogło ono objąć cały Kościół/Rzym, Azja, Egipt/ przed napisaniem ewangelii, czy raczej nie bardziej prawdopodobna jest sytuacja, iż istniente środowiska Janowego w Rzyme, Egipcie, Azji było wynikiem istniejacej już 1 czytanej ewangelii Jana. Sądzimy, iź to właśnie sugerują nam omawiane dokumenty starozytne;

$4^{\circ}$ podtrzymujemy nadal, iż zauważone aluzje nawiązywania do IV ewangelii wajwcześniejszych dokumentach chrześcijańskich stanowia najstarsza Pazę jej egzegezy. Polegała ona na tym, iz w wykadzie doktryny chrześcijańskiej korzystano z gotowych sformułowań Janowych. Brak przykładania uwagi do dokładnego cytowania płynął m.in. z niemystępowania błędnych interpretacji tekstu;

$5^{0}$ o ile to ostatnie stwierdzenie jest słuszne, należałoby się spodziewać, iż wraz $z$ pojawieniem się literatury apologetycznej nastappi pewna zmiana w sposobie wykładu IV ewangelii.

Ks. Antoni Paciorek - Tarnów

\section{DE EXEGESI IV EVANGELII IN SCRIPTIS PATHUM APOSTOLICORUM /Argumentum/}

Hoc in brevi articulo expositum est, quomodo locutiones ac ideae Joannis evangelistae in selectis scriptis/Epistola Clementis Romani ad Corinthios, Epistolae Ignatil Antiocheni, Epistola Barnabae/ mutuatae sint. In his enim operibus adhuc numquam ulla plena sententia ex IV evangelio excerpta directe allata est. 